\title{
KONFORMITAS DAN KEMATANGAN EMOSI DENGAN PERILAKU AGRESI PADA SISWA KELAS XI SMK X DI JAKARTA TIMUR
}

\author{
Resti Septina Damayanti \\ Rilla Sovitriana
}

\begin{abstract}
Abstrak
Tujuan penelitian untuk mengetahui hubungan konformitas dan kematangan emosi dengan perilaku agresi pada siswa kelas XI SMK X Jakarta Timur. Populasi penelitian adalah siswa kelas XI SMK X Jakarta Tim yang berjumlah 140 orang, yang dijadikan sampel berdasarkan tabel Krejcie - Morgan berjumlah 103 orang menggunakan proportional random sampling. Hasil uji coba instrumen skala konformitas diperoleh Cronbach's Alpha if Item Deleted sebesar

0,536 - 0,856.Untuk skala kematangan emosi diperoleh Cronbach's Alpha if Item Deleted sebesar 0,406 - $\mathbf{0 , 8 3 0}$. Hasil analisis data bivariate correlation pada konformitas dengan perilaku agresi diperoleh $r=0,595$ dengan $p=0,000<0,05$. Sehingga $\mathrm{Ha}_{1}$ yang menyatakan "ada hubungan konformitas dengan perilaku agresi pada siswa kelas XI SMK Jakarta Timur" diterima. Hasil analisis data bivariate correlation pada kematangan emosi dengan perilaku agresi diperoleh $\mathbf{r}=-$ 0,310 dengan $p=0,001<0,05$. Sehingga $\mathrm{Ha}_{2}$ yang menyatakan "ada hubungan kematangan emosi dengan perilaku agresi pada siswa kelas XI SMK $X$

Jakarta Timur" diterima. Koefisien korelasi multivariate correlation konformitas dan kematangan emosi dengan perilaku agresi diperoleh $R=0,639$ dengan $p=0,000<$ 0,05. Sehingga $\mathrm{Ha}_{3}$ yang menyatakan "ada hubungan kematangan emosi dengan perilaku agresi pada siswa kelas XI SMK Jakarta Timur”.
\end{abstract}

Kata Kunci : Konformitas, Kematangan Emosi, Perilaku Agresi 


\section{PENDAHULUAN}

Belakangan ini kita telah dikejutkan dengan adannya berbagai macam kasus kenakalan remaja yang semakin menyimpang. Berbagai macam kasus kenakalan remaja yang dimaksud antara lain saling ejek satu sama lain atau antar sekolah, tawuran dan yang semakin meresahkan adalah, tindak kenakalan remaja yang masuk dalam kategori kriminal yaitu pencurian dan pembegalan yang dilakukan oleh anakanak usia remaja belakangan ini.

Perilaku tersebut merupakan tindakan yang sangat merugikan orang lain dan tentunya diri sendiri. Tindakantindakan seperti itu merupakan identitas yang ditunjukkan anak-anak remaja dalam mencari jati diri serta menunjukkan bahwa usia remaja adalah masa dimana mereka dapat memberontak dan juga melanggar aturan yang telah dibuat di dalam masyarakat, sekolah, dan keluarga. Di Indonesia kasus kenakalan remaja bukan lagi hal yang biasa melainkan hal yang patut untuk di waspadai karena semakin bertambah setiap tahunnya. Sebanyak 12 kasus menyebabkan kematian.

Kasus geng motor yang semakin brutal sangat meresahkan. Terdapat tiga perilaku buruk geng motor yaitu, balapan liar, pengroyokan, dan judi dengan bentuk taruhan.Aksi brutal geng motor di Jakarta telah menewaskan 60 orang setiap tahunnya.Sementara pada tahun 2011 terdapat 339 kasus tawuran menyebabkan 82 anak meninggal dunia.Demikian hingga bulan Juni tahun 2012 terjadi 139 kasus tawuran di Jakarta. Sebanyak 12 kasus menyebabkankematian(http://abredenk8 9.blogspot.co.id).

Dari sekian banyak kasus kenakalan remaja di Jakarta, kasus yang paling memprihatinkan dan masih banyak terjadi sampai saat ini adalah tawuran antar pelajar. Perilaku siswa untuk saling mengejek satu sama lain, ataupun mengejek-ejek sekolah lain, hal tersebut dapat menimbulkan provokasi bagi sebagian pelajar remaja yang dapat membahayakan kedua belah pihak sehingga mengarahkan pada terjadinya perilaku agresi yaitu perkelahian antar pelajar atau yang dikenal dengan tawuran. Perilaku agresi merupakan perilaku yang dapat membahayakan atau menyakiti seseorang secara fisik maupun mental. Orang dengan perilaku tersebut cenderung menyerang. Baron dan Byrne (2005:137) menyebutkan bahwa perilaku agresi adalah tingkah laku yang diarahkan kepada tujuan menyakiti makhluk hidup lain yang ingin menghindari perlakuan semacam itu. Pendapat lain disampaikan oleh Lorenz (dalam Baron dan Byrne, 
2005:137) bahwa agresi muncul terutama dari insting berkelahi (fighting instinct) bawaan yang dimiliki oleh mausia dan spesies lainnya.

Perilaku agresi merupakan salah satu perilaku yang terkadang ditunjukkan oleh siswa, beberapa aktivitas yang dilakukan oleh remaja tidak sesuai dengan keinginan yang ada dalam diri siswa sehingga remaja terkadang meluapkan energi yang dimiliki kearah negatif seperti perilaku agresi (Auliya dan Nurwidawati, 2014:

1).Bukan hanya masalah fisik, perilaku agresi terkadang ditunjukkan melalui verbal atau ucapan yang menyakiti sehingga saling menghina, mengejek dan berteriak yang menunjukkan kemarahan pada individu.

Perilaku agresi yang dilihatkan oleh remaja merupakan perilaku yang menunjukkan adanya rasa ingin mencelakai seseorang baik fisik maupun mental. Biasanya keadaan seperti ini merupakan provokasi dari luar yaitu teman atau kelompok tertentu. Kelompok biasanya memiliki hubungan yang kuat dan memiliki kelekatan antara individu dengan individu yang lain. Baron dan Byrne (2005:175) menyebutkan bahwa kelompok adalah sekumpulan orang yang dipersepsikan terikat satu sama lain dalam sebuah unit yang koheren pada derajat tertentu.
Dalam kehidupan berkelompok, setiap kelompok memiliki aturan yang digunakan untuk mengatur anggotanya. Setiap anggotanya harus mentaati aturan-aturan yang ditetapkan kelompok tanpa diminta. Hal inilah yang disebut dengan konformitas. Konformitas adalah suatu jenis pengaruh sosial di mana individu mengubah sikap dan tingkah laku mereka agar sesuai dengan norma yang ada.

Wilujeng (2013:7) mengatakan bahwa, individu akan melakukan tindakan sesuai dengan harapan-harapan kelompok sosial dimana perilaku tersebut merupakan ekspresi persetujuan pada norma-norma kelompok. Konformitas terjadi apabila sejumlah orang dalam kelompok mengatakan atau melakukan sesuatu, ada kecenderungan para anggota untuk mengatakan dan melakukan hal yang sama (Silalahi dan Utami, 2013:94). Kenyataan seperti ini membuat individu merasa bangga bahwa dirinya di anggap dalam sebuah kelompok, sebab jika tidak ikut melakukan suatu tindakan yang diperintahkan, maka individu tersebut dianggap bukan anggota kelompok. Individu dengan kematangan emosi yang baik dapat memilih dengan tepat jika konformitas dari suatu kelompok dianggap negatif dan merugikan orang lain. Emosi yang bersifat negatif yang di 
sertai dorongan dari luar seperti provokasi, membuat penyaluran energi negatif berupa dorongan agresi yang dapat memengaruhi perilaku individu. Emosi merupakan suatu perasaan yang mendorong individu untuk merespons atau bertingkah laku terhadap stimulus, baik dari dalam maupun dari luar dirinya (Wahab, 2015:158-159).

Seseorang yang mengalami emosi pada umumnya tidak lagi memperhatikan keadaan sekitar, sesuatu aktivitas tidak dilakukan oleh seseorang dalam keadaan normal (Walgito, 2004:209). Remaja dengan tingkat kematangan emosi yang tinggi, dapat memahami situasi-situasi dengan baik dan tidak mudah terprovokasi dalam hal yang dapat merugikan orang lain maupun dirinya sendiri. Anak laki-laki dan perempuan dikatakan sudah mencapai kematangan emosi bila pada akhir masa remaja tidak meledakkan emosinya di hadapan orang lain melainkan menunggu saat dan tempat yang lebih tepat untuk mengungkapkan emosinya dengan cara-cara yang lebih dapat diterima (Hurlock, 2015: 212).

Pada penelitian yang dilakukan oleh Arief Nurtjahyo dan Andik Matulessy (2013: 225) dikatakan bahwa berbagai penelitian telah dilakukan untuk mencari cara bagaimana menanggulangi atau, paling tidak, mengurangi perilaku agresif, khususnya bagi pelajar dan mahasiswa. Dari berbagai faktor yang mempengaruhi, kematangan emosi dan konformitas dianggap sebagai dua faktor yang cukup penting dalam mempengaruhi perilaku agresif.

Rumusan masalah dari penelitian ini adalah: (1) bagaimana hubungan antara konformitas dengan perilaku agresi pada siswa kelas XI SMK X Jakarta Timur? (2) bagaimana hubungan antara kematangan emosi dengan perilaku agresi pada siswa kelas XI SMK X Jakarta Timur? Bagaimana hubungan antara konformitas dan kematangan emosi dengan perilaku agresi pada siswa kelas XI SMK $\mathrm{X}$ Jakarta Timur?.

Tujuan dari penelitian ini adalah: (1) untuk mengetahui hubungan antara konformitas dengan perilaku agresi pada siswa kelas XI SMK X Jakarta Timur. (2) untuk mengetahui hubungan antara kematangan emosi dengan perilaku agresi pada siswa kelas XI SMK X Jakarta Timur. (3) untuk mengetahui hubungan antara konformitas dan kematangan emosi dengan perilaku agresi pada siswa kelas XI SMK X Jakarta Timur. 
TINJAUAN PUSTAKA

\section{A. Perilaku Agresi}

\section{Pengertian Perilaku Agresi}

Agresi menurut Myers (2012:69) adalah perilaku fisik atau verbal yang bertujuan untuk menyakiti orang lain. Perilaku yang termasuk dalam definisi agresi ini, yaitu menendang dan menampar, mengancam dan menghina, bahkan bergunjing (gosip) atau menyindir. Perilaku lain yang termasuk dalam batasan definisi agresi, yaitu menghancurkan barang, berbohong, dan perilaku lainnya yang memiliki tujuan untuk menyakiti.

Arifin (2015:262) meyatakan bahwa agresi adalah perilaku yang bermaksud untuk membuat objeknya mengalami bahaya atau kesakitan. Agresi adalah setiap bentuk keinginan (drive-motivation) yang diarahkan pada tujuan untuk menyakiti atau melukai sesorang. Agresi dapat dilakukan secara verbal atau fisik. Menurut Sarwono dan Meinarno (2009:162) agresi merupakan tindakan melukai yang disengaja oleh seseorang atau institusi terhadap orang atau institusi lain yang sejatinya disengaja.

Scheneiders (dalam Nando et al, 2014:24) mengatakan bahwa agresi merupakan luapan emosi sebagai reaksi terhadap kegagalan individu yang ditampakan dalam bentuk kesengajaan yang diekspresikan dengan kata-kata (verbal) dan perilaku non verbal.

\section{Aspek-aspek Perilaku Agresi}

Buss dan Perry (1992:452-459) menyatakan bahwa terdapat beberapa aspek yang mewakili perilaku agresi manusia, yaitu:

a. Agresi fisik

Merupakan komponen dari perilaku motorik seperti melukai dan menyakiti orang lain secara fisik.

b. Agresi verbal

Merupakan komponen dari perilaku motorik seperti melukai dan menyakiti orang lain dengan menggunakan verbalisasinya.

c. Kemarahan

Merupakan komponen emosi atau afektif, dimana suatu kondisi dalam diri individu dipengaruhi oleh kontrol emosi

d. Permusuhan

Merupakan komponen kognitif seperti perasaan benci dan curiga pada orang lain.

\section{Faktor-faktor yang Mempengaruhi}

\section{Perilaku Agresi}

Terdapat beberapa faktor sosial, pribadi, dan situasional yang mempengaruhi perilaku agresi menurut Baron dan Byrne, (2005: 143-148), yaitu: 


\section{a. Faktor sosial}

1. Frustasi

Merupakan suatu pengalaman yang tidak menyenangkan.

\section{Provokasi}

Tindakan oleh orang lain yang cenderung memicu agresi pada diri si penerima.

3. Agresi yang dipindahkan

Agresi terhadap seseorang yang bukan sumber dari provokasi yang kuat.

4. Kekerasan media

Agresi di antara penonton menyebabkan melemahnya pertahanan untuk menolak melakukan agresi.

5. Keterangsangan yang meningkat emosi, kognisi, dan agresi

Keterangsangan agresi masih tetap ada setelah melalui situasi di mana hal itu terjadi dan salah diinterpretasikan sebagai rasa marah.

\section{b. Faktor pribadi}

1. Pola perilaku tipe A: meliputi tingkat kompetitif, urgensi waktu, dan hostility yang tinggi.

2. Pola perilaku tipe B: meliputi karakteristik-karakteristik yang berhubungan dengan pola perilaku tipe A

3. Agresi hostile: agresi untuk melakukan suatu kekerasan pada korban

4. Agresi istrumental: agresi yang tujuan utamanya bukan untuk menyakiti korban tetapi untuk mencapai tujuan lain tertentu.

5. Bias atribusional hostile: mempersepsikan maksud dalam tindakan orang lain ketika tindakan ini dirasa ambigu.

6. Narsisme: berlebihan dalam memegang pandangan akan nilai dirinya sendiri.

7. Perbedaan gender: pria lebih cenderung untuk terlibat dalam perilaku seperti ini daripada wanita.

\section{c. Faktor situasional}

1. Suhu udara

Meningkatkan agresi hanya sampai titik tertentu.Di atas tingkat tertentu, agresi menurun selagi suhu udara meningkat.

2. Konsumsi alkohol

Kecenderungan agresi cukup rendah menjadi lebih agresif dalam pengaruh alkohol dan pada individu dalam keadaan normal menunjukkan tingkat agresi yang rendah.

\section{B.Konformitas}

\section{Pengertian Konformitas}

Menurut Santrock (2007:60) konformitas terjadi apabila individu mengadopsi sikap atau perilaku orang lain karena merasa didesak orang lain (baik desakan nyata atau hanya bayangan saja), desakan untuk konform pada kawan-kawan sebaya cenderung 
sangat kuat selama masa remaja. Konformitas terhadap desakan kawankawan sebaya dapat bersifat positif ataupun negatif.

Sarwono dan Meinarno (2009:105-106) menyebutkan bahwa manusia cenderung mengikuti aturanaturan yang ada dalam lingkungannya serta melakukan tindakan yang sesuai dengan norma sosial. Konformitas adalah suatu bentuk pengaruh sosial di mana individu mengubah sikap dan tingkah lakunya agar sesuai dengan norma sosial (Baron dkk, dalam Sarwono dan Meinarno, 2009:106)

\section{Aspek-aspek Konformitas}

Menurut Sears, dkk (1985: 85) ada beberapa aspek konformitas, yaitu:

a. Kekompakan

Kekompakan merupakan suatu kekuatan yang menyebabkan remaja tertarik pada suatu kelompok dan menjadi anggota kelompok tersebut.

b. Kesepakatan

Remaja yang dihadapkan pada keputusan kelompok yang sudah bulat akan mendapat tekanan yang kuat untuk menyesuaikan pendapatnya

c. Ketaatan

Ketaatan merupakan sesutau
yang dilakukan serta terbuka sehingga
terlihat oleh umum walaupun hatinya
tidak setuju.

\section{Ciri-ciri Konformitas}

Menurut Baron dan Byrne (2005: 53) terdapat beberapa ciri-ciri konformitas, yaitu:

a. Kesepakatan

Suatu bentuk pengaruh sosial yang meliputi permintaan langsung seseorang pada orang lain.

b. Kepatuhan

Suatu bentuk pengaruh sosial di mana seseorang hanya perlu memerintahkan satu orang lain atau lebih untuk melakukan satu atau beberapa tindakan.

c. Indoktrinasi intensif

Suatu proses yang dilalui individu untuk menjadi anggota suatu kelompok dan meneriam belief serta aturan-aturan dari kelompok tanpa banyak bertanya.

d. Norma sosial

Aturan yang mengindikasikan bagaimana individu seharusnya bertingkah laku pada suatu situasi yang spesifik.

\section{C.Kematangan Emosi}

\section{Pengertian Kematangan Emosi}

Emosi menurut Goleman (2016: 409) adalah suatu perasaan dan pikiranpikiran khasnya, suatu keadaan biologis dan psikologis, dan serangkaian kecenderungan untuk bertindak.Sementara menurut Santrock (2007:200) emosi adalah perasaan atau 
afek yang muncul ketika seseorang dalam status atau interaksi yang penting baginya, terutama bagi kesejahteraannya.

\section{Sedangkan kematangan emosi}

menurut Hurlock (2015:213) adalah reaksi emosional yang stabil, tidak berubah-ubah dari satu emosi atau suasana hati ke suasana hati yang lain.

Adapun menurut Chaplin (2004: 165) kematangan emosi adalah satu keadaan atau kondisi mencapai tingkat kedewasaan dari perkembangan emosional dan karena itu pribadi yang bersangkutan tidak lagi menampilkan pola emosional yang pantas bagi anakanak.

\section{Aspek-aspek Kematangan Emosi}

Menurut Walgito dalam

(Guswani dan Kwuryan, 2011:88) aspek-aspek kematangan emosi adalah:

a. Dapat menerima keadaan dirinya maupun orang lain seperti apa adanya.

b. Tidak implusif.

c. Dapat mengontrol emosi dan ekspresi emosinya dengan baik.

d. Dapat berfikir secara objektif dan realistis

e. Mempunyai tanggung jawab yang baik.

\section{Karakteristik Kematangan Emosi}

Hurlock

(2015:213)

mengemukakan tiga karakteristik dari kematangan emosi antara lain: a. Kontrol emosi

Individu tidak meledakkan emosinya di hadapan orang lain dan mampu menunggu saat dan tempat yang tepat untuk mengungkapkan emosinya dengan caracara yang dapat diterima.

b. Pemahaman diri Memiliki reaksi emosional yang stabil, tidak berubah-ubah dari satu emosi atau suasana hati ke suasana hati yang lain.

c. Berpikir kritis

Mampu menilai situasi secara kritis terlebih dulu sebelum bereaksi secara emosional.

\section{METODOLOGI PENELITIAN}

Skala yang digunakan dalam penelitian ini adalah skala perilaku agresi, skala konformitas dan skala kematangan emosi. Metode pengumpulan data berupa kuesioner menggunakan model skala likert yang berisikan sejumlah pernyataan yang tertulis dan disebarkan kepada responden dengan memberikan lima alternatif jawaban, dengan jumlah sampel 103 responden. Perngujian ini dilakukan dengan menggunakan rumus Product MomentPearson dan dikerjakan dengan menggunakan program SPSS versi 20.0 for windows. 


\section{ANALISIS DATA DAN \\ PEMBAHASAN}

Dari hasil penelitian untuk menguji hipotesis secara bivariate antara variabel konformitas dan perilaku agresi diperoleh nilai koefisien korelasi sebesar $\mathrm{r}=0,595$ dengan $\mathrm{p}=0,000$ sehingga $\mathrm{p}<$ 0,05. Maka diketahui bahwa terdapat hubungan signifikan dengan arah korelasi positif antara konformitas dengan perilaku agresi. Hal ini menunjukkan ada hubungan antara konformitas dengan kematangan emosi pada siswa kelas XI SMK X

Jakarta Timur. Hal ini sesuai dengan yang telah dikemukakan oleh Santrock (2007 :60) konformitas terjadi apabila individu mengadopsi sikap atau perilaku orang lain karena merasa didesak orang lain (baik desakan nyata atau hanya bayangan saja), desakan untuk konform pada kawan-kawan sebaya cenderung sangat kuat selama masa remaja. Konformitas terhadap desakan kawankawan sebaya dapat bersifat positif ataupun negatif.

Pendapat tersebut dikuatkan dengan penelitian sebelumnya yang dilakukan oleh Puput Wilujeng dan Meita Santi Budiani (2012 : 9) yang menunjukkan bahwa terdapat hasil positif yang signifikan antara konformitas dengan perilaku agresi. Artinya semakin tinggi konformitas seseorang maka akan semakin tinggi pula perilaku agresi yang dimilikinya.

Hasil penelitian untuk uji hipotesis secara bivariate antara variabel kematangan emosi dengan perilaku agresi diperoleh koefisien korelasi sebesar $r=-0,310$ dengan $p=0,001$ sehingga $\mathrm{p}<0,05$. Maka diketahui bahwa terdapat hubungan yang signifikan dengan arah korelasi negatif antara kematangan emosi dengan perilaku agresi. Hal ini menunjukkan ada hubungan antara kematangan emosi dengan perilaku agresi pada siswa kelas XI SMK X Jakarta Timur.

Hal ini sesuai dengan penelitian sebelumnya yang dilakukan oleh Aprius Maduwita Guswani dan Fajar Kawuryan (2011:88) yang menunjukkan bahwa ada hubungan negatif antara kematangan emosi dengan perilaku agresi.Artinya semakin tinggi kematangan emosi maka semakin rendah perilaku agresi.

Hasil penelitian ini searah dengan hasil penelitian yang dilakukan oleh Arief Nurtjahyo dan Andik Matulessy (2013:227) yang menyatakan bahwa ada hubungan negatif yang signifikan antara kematangan emosi dengan perilaku agresi.Artinya semakin tinggi kematangan emosi maka semakin rendah perilaku agresinya.

Berdasarkan hasil analisis Multivariate Correlation diperoleh 
koefisien korelasi $\mathrm{R}$ antara konformitas dan kematanan emosi dengan perilaku agresi sebesar 0,639. Dengan kata lain, ada hubungan yang signifikan antara konformitas dan kematangan emosi dengan perilaku agresi pada siswa kelas XI SMK X Jakarta Timur.

$$
\text { Hasil kategorisasi pada }
$$
penelitian ini, skor konformitas berada dalam kategori tinggi, hal ini dapat diketahui dengan mean temuan sebesar 67.65. Selanjutnya untuk skor kematangan emosi dalam kategori tinggi dengan mean temuan sebesar 61.68. kemudian skor perilaku agresi termasuk dalam kategori tinggi dengan mean temuan sebesar 85.24. Dari hasil penelitian konformitas dan kematangan emosi memiliki hubungan yang signifikan dengan perilaku agresi. Artinnya semakin baik konformitas dan kematangan emosi yang dimiliki maka perilaku agresi yang dilakukan semakin rendah.

Kontribusi konformitas dan kematangan emosi terhadap perilaku agresi dalam penelitian ini sebesar $40,9 \%$, sisanya dijelaskan oleh variabelvariabel lain diluar penelitian. Dari uraian diatas maka hasil penelitian ini dapat memperkuat pernyataan yang menyatakan bahwa ada hubungan antara konformitas dan kematangan emosi dengan perilaku agresi pada siswa kelas XI SMK X Jakarta Timur.

\section{KESIMPULAN}

\begin{tabular}{lrr}
\multicolumn{3}{c}{ Berdasarkan hasil analisis } \\
multivariate menujukkan & adanya \\
pengaru yang & signifikan & antara \\
konformitas dan & kematangan & emosi \\
dengan perilaku agresi pada siswa kelas
\end{tabular} XI SMK X Jakarta Timur.

Sedangkan berdasarkan hasil analisis korelasi bivariate antara konformitas dan perilaku agresi pada siswa kelas XI SMK X Jakarta Timur menunjukkan ada hubungan dengan arah positif. Hal ini berarti jika siswa mempunyai sikap konformitas yang tinggi, maka perilaku agresinya semakin tinggi. Begitu pula sebaliknya, siswa yang mempunyai konformitas yang rendah maka perilaku agresinya rendah.

$$
\text { Berdasarkan hasil analisis }
$$

korelasi bivariate antara kematangan emosi dan perilaku agresi pada siswa kelas XI SMK X Jakarta Timur menunjukkan ada hubungan dengan arah negatif. Hal ini berarti jika siswa mempunyai sikap kematangan emosi yang tinggi, maka perilaku agresinya rendah. Begitu pula sebaliknya, siswa yang mempunyai kematangan emosi yang tinggi maka perilaku agresinya rendah. 


\section{DAFTAR PUSTAKA}

Arifin, Dr. Bambang Syamsul, M.Si, 2015. Psikologi Sosial, Cetakan 1.Bandung : CV Pustaka Setia.

Auliya, Miftah., Nurwidawati, Desi., (2014), "Hubungan

Kontrol Diri Dengan Perilaku Agresi Pada Siswa SMA Negeri 1 Padangan Bojonegoro". Character, Vol. 02. No.3

Baron, Robert. A., Byrne, Donn, 2005. Psikologi Sosial, Edisi kesepuluh, Jilid 2, PT. Gelora Aksara Pratama, Penerbit Erlangga.

Chaplin, J.P., 2004. Kamus Lengkap Psikologi, Cetakan Kesembilan. Jakarta : PT RajaGrafindo Persada.

Guswani, Aprius Maduwita., Kawuryan, Fajar. (2011), "Perilaku Agresi pada Mahasiswa ditinjau dari Kematangan Emosi”, Jurnal Psikologi Pitutur, Vol.I No 2.

Hurlock, Elizabeth B, 2015.Psikologi Perkembangan, Edisi kelima. Penerbit Erlangga

Myers., G. David., 2012. Psikologi Sosial, Edisi 10, Buku 2.Jakarta : Salemba Humanika

Nando., Pandjaitan Nurmala K., (2012). "Hubungan Antara Perilaku Menonton Film Kekerasan Dengan Perilaku Agresi Remaja".
Jurnal Psikologi, Vol. 6 No. 1.

Nurtjahyo, Arief., Matulessy, Andik. (2013), "Hubungan Kematangan Emosi dan Konformitas Terhadap Agresivitas Verbal”, Jurnal Psikologi Indonesia, Vol. 2 No. 3.

Santrock, John W., 2007. REMAJA, Edisi Kesebelas, Jilid 2.

Sarwono, Sarlito W., Meinarno, Eko A, 2009. Psikologi Sosial. Jakarta : Salemba Humanika

Sears, David O., Freedman, Jonathan L, 1985. Psikologi Sosial, Edisi kelima, Jilid 2. Penerbit Erlangga.

Utami, Fransisca Nurmalita Hapsari, Silalahi, Betty Yuliani., (2013), "Hubungan Antara Identitas Sosial Dan Konformitas Pada Anggota Komunitas Virtual Kaskus Regional Depok". Jurnal Proceeding Psikologi, Vol. 5.

Walgito, Prof. Dr. Bimo, 2004. Pengantar Psikologi Umum, Yogyakarta : ANDI

Wilujeng, Puput., Budiani, Meita, Santi, S.Psi. (2013), "Pengaruh Konformitas Pada Geng Remaja Terhadap Perilaku Agresi Di SMK PGRI 7 Surabaya", Jurnal Penelitian Psikologi, Vol. 1 No, 2. 